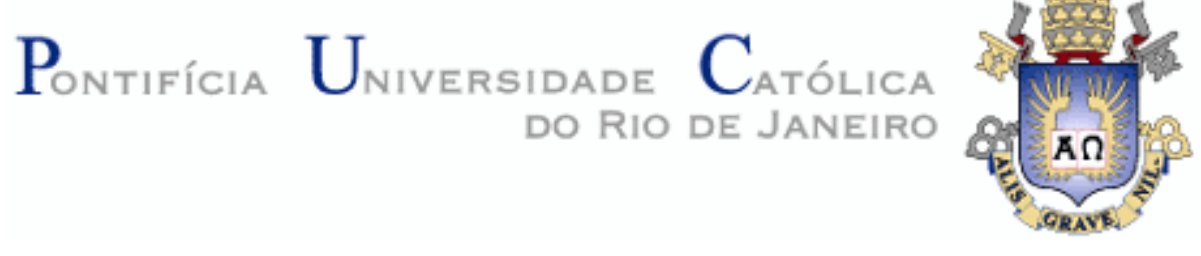

Viviane Mauricio Figueiredo

Serviço Social e Política de Saúde no Brasil: estudo de uma experiência em um hospital universitário

Dissertação de Mestrado

Dissertação apresentada ao Programa de PósGraduação em Serviço Social da PUC-Rio como requisito parcial para obtenção do grau de Mestre em Serviço Social.

Orientadora: Profa. Inez Terezinha Stampa 


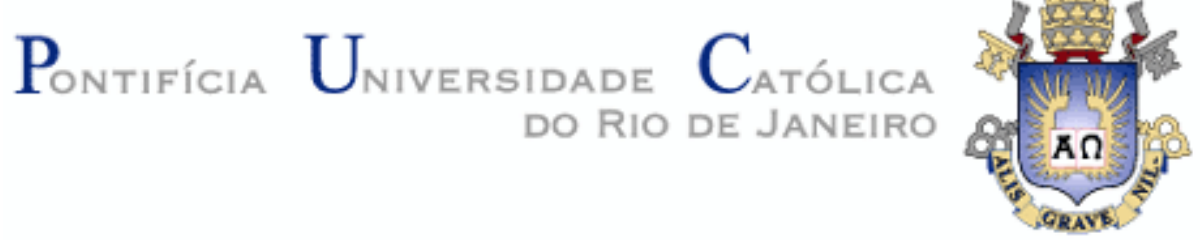

Viviane Mauricio Figueiredo

\section{Serviço Social e Política de Saúde no Brasil: estudo de uma experiência em um hospital universitário}

Dissertação apresentada como requisito parcial para obtenção do grau de Mestre pelo Programa de Pós-Graduação em Serviço Social do Departamento de Serviço Social do Centro de Ciências Sociais da PUC-Rio. Aprovada pela Comissão Examinadora abaixo assinada.

Profa. Inez Terezinha Stampa Orientador Departamento de Serviço Social - PUC-Rio

Prof. Rafael Soares Gonçalves Departamento de Serviço Social - PUC-Rio

Prof. Júlio Alberto Wong Un

UFF

Profa. Mônica Herz

Vice-Decana de Pós-Graduação do Centro de Ciências Sociais - PUC-Rio 
Todos os direitos reservados. É proibida a reprodução total ou parcial do trabalho sem autorização da universidade, da autora e da orientadora.

\section{Viviane Mauricio Figueiredo}

Graduou-se em Serviço Social pela Universidade Federal do Rio de Janeiro em 2005, cursou Residência em Serviço Social e Saúde pelo Hospital Universitário Pedro Ernesto/UERJ no período de 2007 a 2009, cursou Especialização em Serviço Social e Saúde pela Universidade do Estado do Rio de Janeiro no período de 2009 a 2010. Atualmente é membro da Comissão de Ética do Conselho Regional de Serviço Social da $7^{\text {a }}$ Região e compõe o Corpo de Militares da Marinha do Brasil como Oficial da área de Serviço Social.

Ficha Catalográfica

Figueiredo, Viviane Mauricio

Serviço social e política de saúde no Brasil: estudo de uma experiência em um hospital universitário / Viviane Mauricio Figueiredo; orientadora: Inez Terezinha Stampa. - 2011.

120 f.; $30 \mathrm{~cm}$

Dissertação (mestrado)-Pontifícia Universidade Católica do Rio de Janeiro, Departamento de Serviço Social, 2011.

Inclui bibliografia.

1. Serviço social - Teses. 2. Política social. 3. Direitos sociais. I. Stampa, Inez Terezinha. II. Pontifícia Universidade Católica do Rio de Janeiro. Departamento de Serviço Social. III. Título. 
Ao maior milagre que poderia receber de Deus e que veio coroar de felicidade o encerramento deste ciclo. 


\section{Agradecimentos}

À professora e orientadora Inez Stampa, uma das pessoas mais atenciosas, educadas e acessíveis que já conheci... A você meu muito obrigado por todo carinho e principalmente pela paciência.

A CAPES e à PUC-Rio, pelos auxílios concedidos, sem os quais este trabalho não poderia ter sido realizado.

Aos colegas de curso, perfis diferentes que se completaram e que principalmente fizeram do café no Bar dos Funcionários um dos momentos mais divertidos e descontraídos desses dois anos... A vocês meu beijo carinhoso e votos de muito, muito sucesso.

Ao meu marido pelo amor, pelo companheirismo, pela proteção, pelo carinho e pela força que sempre chegou na hora certa e nos momentos mais difíceis, principalmente nesta fase final. Maridote você é demais! E eu te amo cada vez mais! 


\section{Resumo}

Figueiredo, Viviane Mauricio; Stampa, Inez Terezinha (Orientadora). Serviço Social e política de saúde no Brasil: estudo de uma experiência em um hospital universitário. Rio de Janeiro, 2011. 120p. Dissertação de Mestrado - Departamento de Serviço Social, Pontifícia Universidade Católica do Rio de Janeiro.

Considerada uma das áreas de maior empregabilidade para o assistente social, a saúde ao longo dos anos tem reservado um espaço de inúmeras produções acadêmicas na área. Essas produções trouxeram para a discussão do Serviço Social na saúde as atividades desenvolvidas pelos profissionais, o trabalho, a multidisciplinaridade e a integralidade das ações que, cotidianamente, podem promover ao usuário do serviço de saúde a possibilidade de acesso a outros direitos sociais. A área da saúde no Brasil passou por marcos de movimentos sociais, como o da Reforma Sanitária e a construção do Sistema Único de Saúde, que hoje se tornou um dos maiores exemplos da idealização e concretização de sistema de saúde pública. Um sistema que garante o acesso universal e acolhe os usuários sob a perspectiva de um conceito ampliado de saúde que compreende o bem estar físico, psicológico e social e interliga a saúde do sujeito a condicionantes como o trabalho, educação, assistência, saneamento básico e lazer, ou seja, outros direitos e benefícios sociais que complementam o atendimento integral ao usuário. Mas este SUS e toda a sua proposta de cuidado em saúde também foi diretamente atingido pelos reflexos de políticas de corte neoliberal e sofreu com as transformações que levaram ao sucateamento dos equipamentos e serviços, bem como da força de trabalho atuante nas unidades de saúde, dentre elas o assistente social. A discussão proposta nesta dissertação tem como objetivo abordar, através de uma análise crítica e construtiva da política de saúde e do espaço institucional da saúde, o trabalho desenvolvido por assistentes sociais de uma unidade de saúde pública de um hospital universitário do Rio de Janeiro, numa equipe multiprofissional.

\section{Palavras-chaves}

Serviço Social; Política Social; Direitos Sociais. 


\section{Abstract}

Figueiredo, Viviane Mauricio; Stampa, Inez Terezinha (Advisor). Social Services and Health Policy in Brazil: a study of experience in a university hospital. Rio de Janeiro, 2011. 120p. MSc. Dissertation - Departamento de Serviço Social, Pontifícia Universidade Católica do Rio de Janeiro.

Considered one of the areas of bigger empregability for the social assistant, the health throughout the years has reserved a space of innumerable academic productions in the area. These productions had brought for the quarrel of the Social Service in the health the activities developed for the professionals, the work, the multidisciplinarity and the completeness of the actions that, daily, can promote to the user of the service of health the possibility of access to other social rights. The area of the health in Brazil passed for landmarks of social movements, as of the Sanitary Reformation and the construction of the Only System of Health that today became one of the biggest examples of the conception and concretion of system of public health. A system that guarantees the universal access and receives the users under the perspective of an extended concept of health that understands the welfare physicist, psychological and social and establish connection the health of subject to they establish conditions as the work, education, assistance, basic sanitation and leisure, that is, other social rights and benefits that complement the integral attendance to the user. But this SUS and all its proposal of care in health also directly was reached by the consequences of politics of neoliberal cut and suffered with the transformations that had taken to the trashing of the equipment and services, as well as of the force of operating work in the units of health, amongst them the social assistant. The quarrel proposal in this research has as objective to approach, through a critical and constructive analysis of the politics of health and the proper space of the institution of the health, the work developed for social assistants of a unit of public health of a university hospital of Rio de Janeiro, Brazil, inside of the multiprofessional team.

\section{Keywords}

Social Service; Social Policy; Social Rights. 


\section{Sumário}

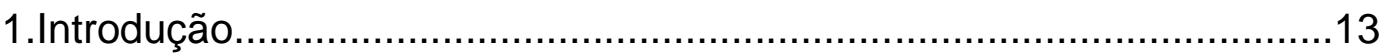

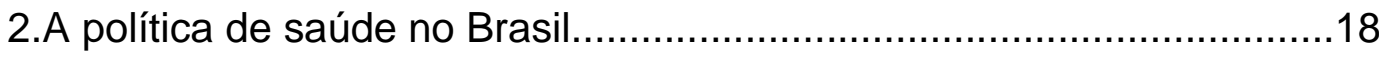

2.1. Política de saúde: trajetória histórica..................................................19

2.2. A década de 1980: Reforma Sanitária e a construção do

Sistema Único de Saúde brasileiro....................................................27

2.3. A década de 1990: o sucateamento do Sistema e a perspectiva de um novo cenário para a política de saúde no Brasil.

3. O Serviço Social e o espaço institucional da saúde como campo de atuação profissional.

3.1. Assistente social - profissional de saúde: possibilidades e desafios em um cenário de desconstrução de direitossociais. 60

3.2. Trabalhando direitos sem ter direitos: as diferentes inserções no espaço institucional das unidades de saúde.

4. O hospital universitário: lócus privilegiado de atenção à saúde. O campo de pesquisa.

4.1. O trabalho desenvolvido por uma equipe de saúde de um núcleo de estudos de um hospital universitário no Rio de Janeiro 73

4.2. A participação do Serviço Social na equipe multidisciplinar: considerações sobre a definição de papéis. 76

5. Comentários finais.

6. Bibliografia 
Anexo A

Termo de Consentimento Livre e Esclarecido.

Anexo B

Roteiro de entrevista .90

Anexo C

Núcleo de Estudos da Saúde do Adolescente - NESA 


\section{Lista de Siglas}

ABIA - Associação Brasileira Interdisciplinar de AIDS

AIDS - Síndrome da Imunodeficiência Adquirida

AIS - Ações Integradas de Saúde

CAP's - Caixas de Aposentadorias e Pensões

CBCISS - Centro Brasileiro de Cooperação e Intercâmbio em Serviços Sociais

CEBES - Centro Brasileiro de Estudo de Saúde

CEPERJ - Fundação Centro Estadual de Estatísticas, Pesquisas e Formação de Servidores Públicos do Rio de Janeiro

CFESS - Conselho Federal de Serviço Social

CIPLAN - Comissão Interministerial de Planejamento e Coordenação

CONASP - Conselho Consultivo da Administração de Saúde Previdenciária

CIS - Comissão Interinstitucional de Saúde

CLINEX - Clínica de Hipertensão do Laboratório de Fisiopatologia Clínica e Experimental

CLIS - Comissão Local ou Municipal de Saúde

CLT - Consolidação das Leis Trabalhistas

CNS - Conferência Nacional de Saúde

CRIS - Comissão Regional Interinstitucional de Saúde

DST's - Doenças Sexualmente Transmissíveis

FBH - Federação Brasileira de Hospitais

FUNCAPE - Fundação Cardiovascular Pedro Ernesto

FUNDARJ - Fundação para Pesquisa e Extensão na Área de Hematologia do Hospital Hemorio

HUPE - Hospital universitário Pedro Ernesto 
IABAS - Instituto de Atenção Básica e Avançada em Saúde

IAPB - Instituto de Aposentadoria e Pensões dos Bancários

IAPC - Instituto de Aposentadorias e Pensões dos Comerciários

IAPETEC - Instituto de Aposentadoria e Pensões dos Empregados em Transportes e Cargas

IAPI - Instituto de Aposentadorias e Pensões dos Industriários

IAPM - Instituto de Aposentadoria e Pensões dos Marítimos

INAMPS - Instituto Nacional de Assistência Médica da Previdência Social

INCA - Instituto Nacional de Câncer

INPS - Instituto Nacional da Previdência Social

IPASE - Instituto de Pensões e Assistência dos Servidores do Estado

LBA - Legião Brasileira de Assistência

MARE - Ministério da Administração Federal e Reforma do Estado

MEC - Ministério da Educação e Cultura

MPAS - Ministério da Previdência e Assistência Social

MS - Ministério da Saúde

MPAS - Ministério da Previdência e Assistência Social

NESA - Núcleo de Estudos da Saúde do Adolescente

OEA - Organização dos Estados Americanos

OMS - Organização Mundial da Saúde

ONGs - Organizações Não-Governamentais

ONU - Organização das Nações Unidas

OPA - Organização Pan-Americana da Saúde

OSCIP - Organização da Sociedade Civil de Interesse Público

OSs - Organizações Sociais

PIASS - Programa de Interiorização das Ações de Saúde e Saneamento do Nordeste

PREV-SAÚDE - Programa Nacional de Serviços Básicos de Saúde 
PS - Pronto Socorro

PSTA - Programa de Saúde do Trabalhador Adolescente

RAMA - Rede de Apoio Docente Assistencial de Atenção à Mulher Adolescente e Jovem

SES - Secretaria de Estado de Saúde do Estado do Rio de Janeiro

SESP - Serviço Especial de Saúde

SUDS - Sistema Unificado e Descentralizado de Saúde

SUS - Sistema Único de Saúde

UEG - Universidade do Estado da Guanabara

UERJ - Universidade do Estado do Rio de Janeiro 